
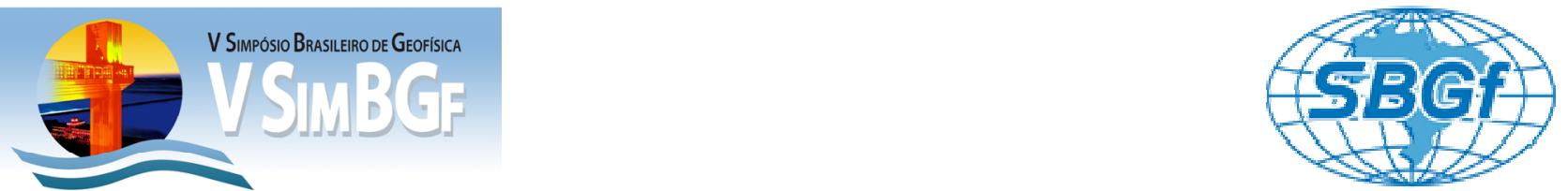

\title{
Geothermal Regime of the World Sedimentary Basins
}

Astakhov S.M.*1 - sergey.m.astakhov@rambler.ru

Reznikov A.N. ${ }^{2}$

${ }^{1}$ OJSC Krasnodarneftegeophysica, ${ }^{2}$ Southern Federal University

Copyright 2012, SBGf - Sociedade Brasileira de Geofísica

Este texto foi preparado para a apresentação no V Simpósio Brasileiro de Geofísica, Salvador, 27 a 29 de novembro de 2012. Seu conteúdo foi revisado pelo Comitế Técnico do V SimBGf, mas não necessariamente representa a opinião da SBGf ou de seus associados. É proibida a reprodução total ou parcial deste material para propósitos comerciais sem prévia autorização da SBGf.

\section{Resume}

The type of geothermal regime is considered as the significant attribute influenced on the paleotemperature reconstruction methodology and heat flow analysis especially in basin modeling approach. That is the relevance of this study related with. A number of generalized equations were obtained by detailed studying of the temperature-depth profiles and various geothermal indicators al over the world. Three main "summarizing" groups of factors were identified. These allowed classifying all equations obtained into 3 classes: Anomalous, Normal and Magmatic intrusions influenced geothermal regimes.

\section{Introduction}

The temperature distribution along the section is considered to be the quintessence of the various factors influencing the final accumulation of hydrocarbons $(\mathrm{HC})$. In this mind, the generalization up-to-date studies on the sedimentary basins geothermal regime characteristics are of great interest.

Temperature-depth profiles and various geothermal indicators in more than 5,000 wells and measurements were studied. 307 equations that characterize the geothermal regime of the various basins were calculated. Certain features of the temperature profiles and calculated equations were identified. It was allowed to classify the sedimentary basins geothermal regimes of the world.

Calculated objects are observed in the overview maps (Fig. 1, 2). World sedimentary basins are delineated. It is shown that almost a half $(40-50 \%)$ of area of the whole world sedimentary basins (identified by drilling and anticipated by rather geophysical data) is taken as calculated. The part of total number of the calculated basins with giant and subgiant oil and gas fields is about $60-70 \%$ of the area of distribution.

\section{Results}

Finding regularities in the behavior of equations was the first task of the interpretation stage of the results with the further to identify the dependences on various factors that affect the thermal regime. Three main "summarizing" groups of factors were identified: 1 . Age of the sediments composing the sedimentary basin 2 . The influence of socalled external geological factors; 3 . Effect of geodynamic excitement (Basin geodynamic type; age of the recent tectonic reconstruction; overthrusting, tectonic inversions etc.). The general form of the equation $(t=a H \pm b)$ allows

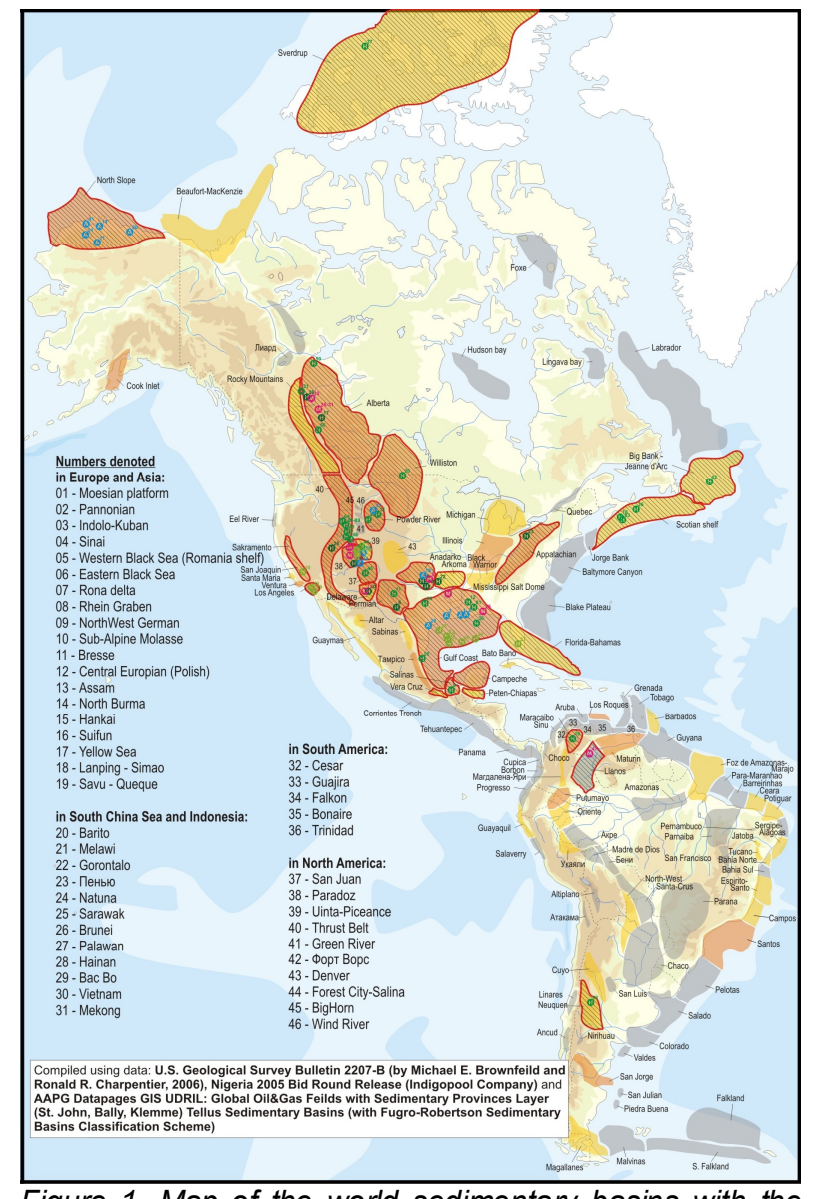

Figure 1. Map of the world sedimentary basins with the geothermal regime calculated (North and South America)

to differentiate equations and thereby the geothermal regimes of two variables: the coefficient of "a», which is the geothermal gradient, and the absolute term of «b», which is the value of the of external geological factors influence roughly speaking. The resulting set of equations is divided into three groups clearly by using magnitude of "b": 1. - With negative values of "b» (the Anomalous regime); 2. - With positive (the Normal regime); 3. - With high positive values (> 50). Branching-off groups (Fig. 3) of the equations have been analyzed primarily in terms of the external factors impact on them. The equations are characterized by different geothermal gradients, since the they are calculated over the geological time intervals (Cenozoic, Mesozoic, Paleozoic) and absolute term "b" can characterize the effect of addition heating or cooling "from the outside" of the steady-state system. The external factors influencing the thermal regime are identified: - the influence of igneous intrusions in the group with high values of "b" (49 equations); - for the 


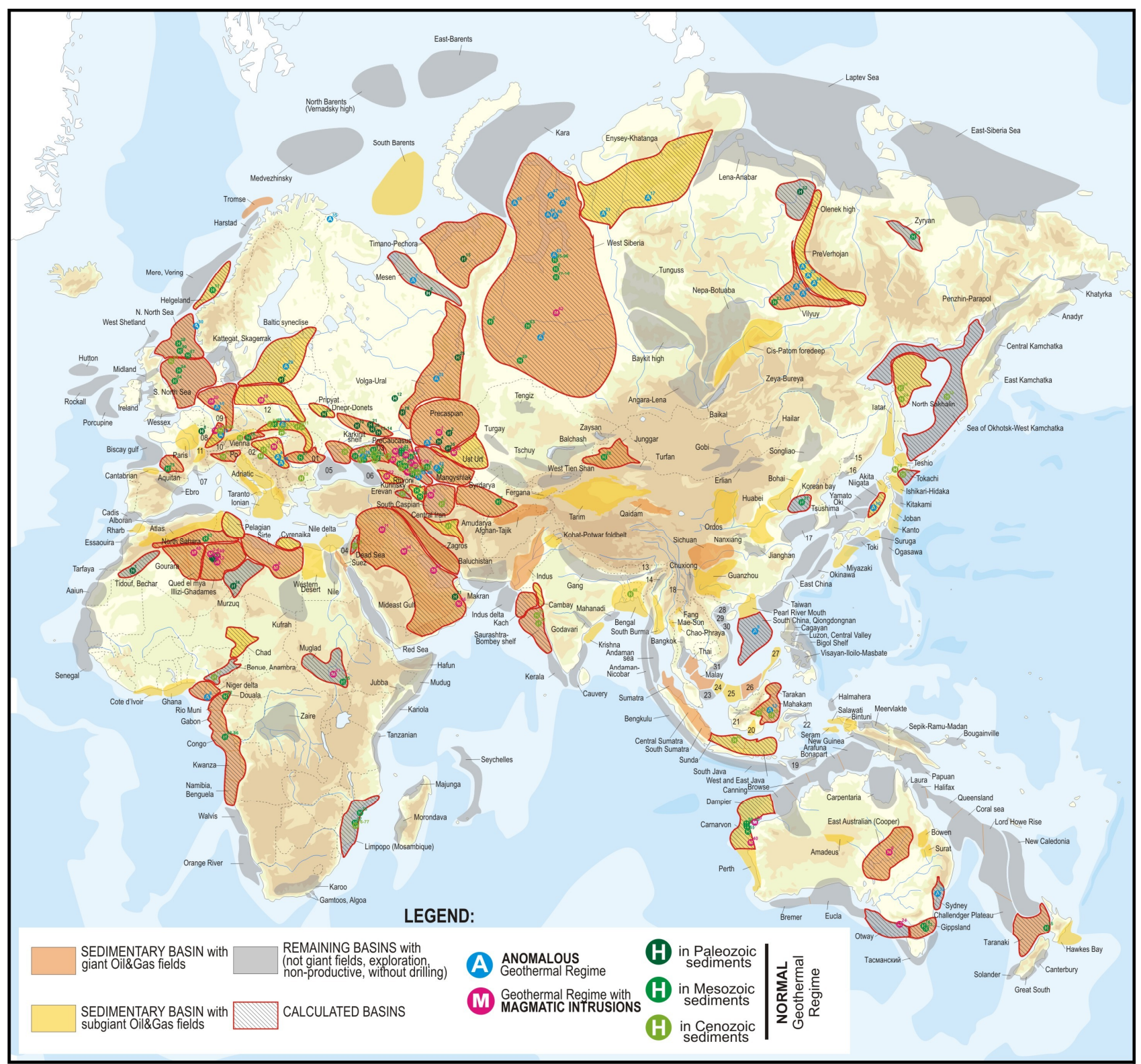

Figure 2. Map of the world sedimentary basins with the geothermal regime calculated (Eurasia, Africa, Australia and Indonesia)

Anomalous regime the binding above all to the gasbearing intervals of the calculated basins is established (48 equations). The estimated equation is mainly localized in the individual basins, but there are individual wells within the Normal regime basins. An additional convective effect of the deep intervals heating by the reason of dry gas saturation should be considered as a possible explanation for the stand-alone Anomalous regime wells within the Normal regime basins, as well as for the whole Normal regime basin never the less. The remaining equations classified to the Normal regime group.
Absolute term «b» shows the behavior of the geothermal gradient (coefficient "a") along the section (Fig. 4), in spite of the fact that the equations have been calculated disjunctively for the age of the sediments. A negative "b" means rising the geothermal gradient towards the surface and the concave shape of the original temperature-depth profile, a positive " $b$ " - means the decreasing of the gradient towards the surface and the convex shape of the profile. 
Table 1. The average equations of different geothermal regimes

\begin{tabular}{|c|c|c|c|c|}
\hline \multirow{3}{*}{$\begin{array}{l}\text { Geothermal regime } \\
\frac{8}{8} \\
\qquad \% \\
\\
\text { Anomalous regime } \\
\text { with negative absolute } \\
\text { term "b" }\end{array}$} & \multicolumn{2}{|c|}{$\begin{array}{l}\text { Everage } \\
\text { equation }\end{array}$} & \multirow{2}{*}{$\begin{array}{l}\mathrm{N} \\
\mathrm{E} \\
\mathrm{q} . \\
10\end{array}$} & \multirow{2}{*}{$\begin{array}{c}\text { Code } \\
\text { in fig. } \\
3 \\
\text { A-PZ }\end{array}$} \\
\hline & PZ & $\begin{array}{c}\mathrm{t}=33.5 \mathrm{H}- \\
14.6\end{array}$ & & \\
\hline & $\mathrm{MZ}$ & $\begin{array}{c}\mathrm{t}=36.1 \mathrm{H}- \\
15.6\end{array}$ & 28 & A-MZ \\
\hline & KZ & $\begin{array}{c}\mathrm{t}=41.3 \mathrm{H}- \\
16.0\end{array}$ & 13 & A-KZ \\
\hline $\begin{array}{l}\text { Regime with high } \\
\text { values of absolute term }\end{array}$ & PZ & $\begin{array}{c}t=22.4 \mathrm{H}+ \\
58.3\end{array}$ & 24 & M-PZ \\
\hline $\begin{array}{l}\text { "b" (influence of the } \\
\text { magmatic intrusions) }\end{array}$ & $M Z$ & $\begin{array}{c}\mathrm{t}=23.2 \mathrm{H}+ \\
55.1\end{array}$ & 20 & M-MZ \\
\hline & $K Z$ & $\begin{aligned} t= & 29.0 \mathrm{H}+ \\
& 65.5\end{aligned}$ & 10 & $\mathrm{M}-\mathrm{KZ}$ \\
\hline $\begin{array}{l}\text { Normal regime in the } \\
\text { Paleozoic sediments }\end{array}$ & \multicolumn{2}{|c|}{$\mathrm{t}=25.9 \mathrm{H}+18.0$} & 35 & $\mathrm{H}-\mathrm{PZ}$ \\
\hline $\begin{array}{l}\text { Normal regime in the } \\
\text { Mesozoic sediments }\end{array}$ & \multicolumn{2}{|c|}{$\mathrm{t}=30.6 \mathrm{H}+17.0$} & 97 & $\mathrm{H}-\mathrm{MZ}$ \\
\hline $\begin{array}{l}\text { Normal regime in the } \\
\text { Cenozoic sediments }\end{array}$ & \multicolumn{2}{|c|}{$t=32.5 H+17.6$} & 78 & $\mathrm{H}-\mathrm{KZ}$ \\
\hline
\end{tabular}

And as mentioned above, the shape of the temperaturedepth plot can point out the different geodynamic types of the basin. The latter, the most important perhaps, factor of geodynamic type is not examined at this stage and still the aim of further research. For cluster and factor analysis of variances of profiles and estimated equations parameters, as a main tasks for further investigation, the following factors are selected: tectonic (geodynamic) basin type from different classification schemes, age of the recent tectonic reconstruction, basin sediment thickness, sedimentation rate, the degree of igneous intrusions influence, the degree of tectonically faulting, such as the asthenosphere depth, erosions and inversions intensity during the basin geological history.

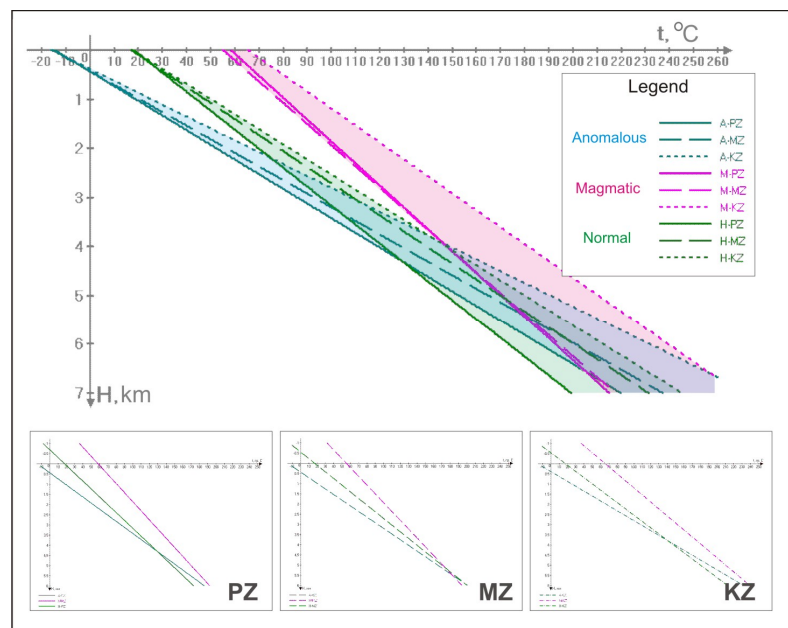

Figure 3. The average equations of different geothermal regimes disjunctively for the age of the sediments

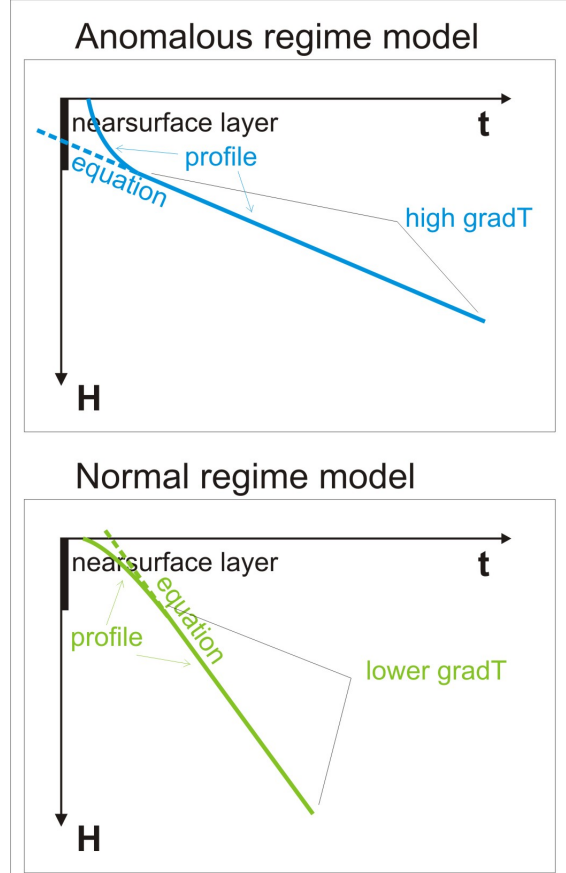

Figure 4. Generalized model of Anomalous and Normal regimes temperature-depth profile

\section{Conclusions and discussion}

It is allowed to make some conclusions about the specifics of the geothermal regime (without regard to the degree of geodynamic basin intensity factor):

A. The anomalous geothermal regime is characterized by the raised parameters of geothermal gradient at depths more than $2 \mathrm{~km}$. The average gradT is $40^{\circ} \mathrm{C} / \mathrm{km}$. Large temperature gradients may indirectly indicate the convective heat transfer due to the heated fluid moving the lower layers of the sedimentary cover by high permeable zones. In this way at depths greater than 6-7 $\mathrm{km}$, by using an extrapolation of equation values, the temperature will be higher than "normal" (Fig. 5). For example, data for the analysis of the constructed maps of Steen River basin (USA) geothermal gradients indicate the association of areas with high geothermal gradients in gas fields and oil with a reduced [6]. However, this assumption should be strictly bind to the tectonic features of the region, in each case and take into account differences in the thermal conductivity of rocks by lithology. More "cold" terms for the upper interval section can be attributed to Joule-Thompson effect (adiabatic expansion of the gas phase with decreasing temperature).

Overall, the anomalous geothermal regime is characterized by:

- Greater warming up subsurface at greater depths (more than 5-6 km);

- Higher (compared to the normals) the average temperature gradients;

- Lower (compared to normals) the temperatures at depths down to 5-6 km; 
- Low temperature gradient in the nearsurface layer (down to $1 \mathrm{~km}$ ).

The regime is characterized by the influence of the socalled convective component of heat flow.

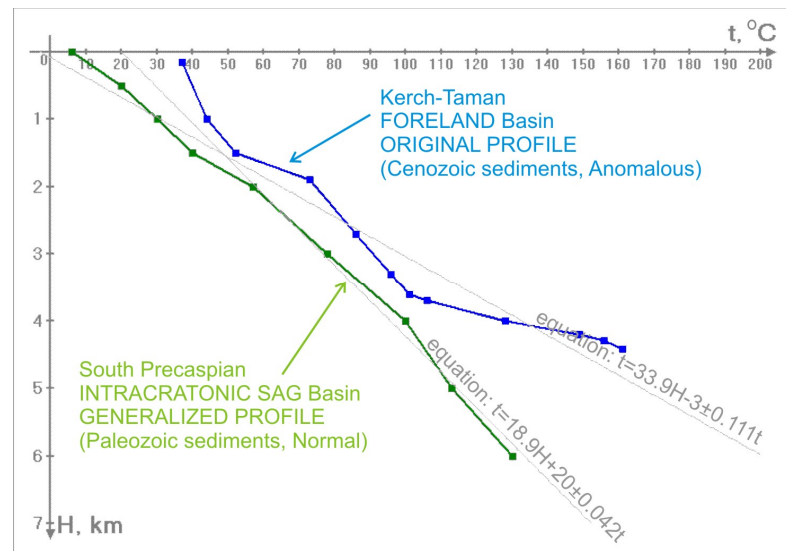

Figure 5. Different geodynamic and geothermal regimes basins example with the calculated equations

B. Changing the temperature with depth in the interval up to $2 \mathrm{~km}$, obeys the law close to the logarithm of the anomalous regime (concave shape of the thermogram), and the power (convex shape of the thermograms) for the normal. In other words, at a nearsurface layer in the anomalous regime, the temperature increases more slowly, and the gradient increases with depth, while the nomal regime is faster and the gradient decreases. It should be noted that we used the values of temperature well logging an average depth interval from $2 \mathrm{~km}$, while plotting the linear regression function.

C. The anomalous geothermal regime is also characterized by a foremost constant geothermal gradient and heat flow uniformity from the basal to the surface. This is possible with long-term heating with a constant or uniformly decreasing basal heat flow, which in turn indicates a tectonic basin maturity, as well as for uniform heating the section by migrating fluids that may occur in the presence of extended conductive fault zones in the area mostly constant gradient.

The criteria, conducted at the beginning of this extended abstract, that make it possible to speak about the basin as "calculated", at the moment not allow to bind a basin to any of the classes. We just have identified trends for future extended classification, which will refine the paleotemperatures forecast based on the geodynamic type of basin, using updated data on the change in heat flow along the section depending on the geodynamic excitement at specific intervals of geologic time.

There is a need for further study and deeper investigation of the issues raised due to the limited database amount. It is possible by the expansion of the database on the thermogram of the world sedimentary basins and using multivariate cluster analysis based on neural networks.

Further research involves the following tasks:

A. Improving reliability of the regularities by gradual elimination of "blank spaces" - uncalculated basin on the world map;

B. Changing regularities identified in connection with obtaining new data;

C. Identification of "typical curve" for different types of basin accordingly to the geodynamic type and its changing history. This will allow to detail paleotemperatures prognosis for the frontier and exploration basins. The geothermal regime will consider the impact of the "geodynamic tension" in addition to conventional elements: the the rock composition, heat flow and paleogeomorphology, the regime of subsidence (sedimentation rate, the basin thickness).

\section{References}

A. T. Hantschel, A.I. Kauerauf, 2009. Fundamentals of Basin and Petroleum Systems Modeling. Berlin: Springer, $476 \mathrm{p}$.

Ju.B. Smirnov, V.I. Kononov, 1980. The thermal field in the USSR: an explanatory note to the maps of heat flow and deep temperatures in the scale of 1:10 000000 . Moscow: Commete of Geodesy and Cartography under the USSR Council of Ministers, $150 \mathrm{p}$.

E.V. Verzhbitsky, M.V. Kononov, 2010. Genesis, tectonic structure and petroleum potential of the lithosphere of the northern oceans. Moscow: Scientific World, $480 \mathrm{p}$.

Yu.I. Galushkin, 2007. Sedimentary basins modelimg and assessment their oil-gas generation, Moscow: Scientific World, $456 \mathrm{p}$.

A.N. Reznikov, 2008. Oil and gas geosynergetics, Rostov-on-Don: CVVR, 303 p.

F.W. Jones, H.L. Lam, 1984. Geothermal gradients in the Steen River area of Northwestern Alberta / / Tectonophysics. Vol. 103, March 1984, p.: 263-272.

G.A. Cheremensky, 1972. Geothermics. Leningrad: Nedra, 271 p.

B.G. Polyak, 1962. About the geothermal gradient of the Russian platform. Writings of the Laboratory of Hydrogeological Problems of the USSR, Vol 42, p.: 25-36.

S.I. Sergienko, 1971. Hydrogeological regime of the Eastern Caucasus. Moscow: Nauka, 152 p.

L.A. Nazarkin, 1979. The influence of sedimentation rate and erosion sections upon oil and gas potentials of sedimentary basins. Saratov: Saratov State University, $336 \mathrm{p}$. 